\title{
Increased expression of cysteine cathepsins in ovarian tissue from chickens with ovarian cancer
}

\author{
Suzie E Ahn ${ }^{\dagger}$, Jin Won Choi ${ }^{\dagger}$, Deivendran Rengaraj, Hee Won Seo, Whasun Lim, Jae Yong Han, Gwonhwa Song
}

\begin{abstract}
Background: Cysteine cathepsins (CTSs) are involved in the degradation and remodeling of the extracellular matrix and are associated with cell transformation, differentiation, motility, and adhesion. These functions are also related to cancer cell invasion and metastasis. Chickens spontaneously develop epithelial ovarian cancer and are therefore a good animal model for human ovarian cancer. However, no studies have investigated the expression of CTSs in chickens with ovarian cancer.

Methods: Cancerous $(n=5)$ and normal $(n=3)$ ovaries were collected from 2-to 3-year-old hens, and ovarian tissue samples were collected for study. Ovarian cancers were evaluated with hematoxylin and eosin staining. Reverse transcriptase and quantitative PCR analyses, in situ hybridization analysis were performed to examine the mRNA expression pattern of three CTSs in detail, and protein expression of CTSB was evaluated.
\end{abstract}

Results: The CTSB, CTSC, and CTSS genes were highly expressed in cancerous chicken ovaries. Messenger RNAs for the three CTSs were localized to a nodule area, a major characteristic of cancerous ovaries, but the three CTSs showed no specific localization in normal ovaries. Immunoreactive CTSB protein was present in the nodule area of cancerous ovaries.

Conclusion: Our results suggest that CTSB, CTSC, and CTSS have important functions in the development of epithelial ovarian cancer.

\section{Background}

Ovarian cancer has the highest mortality rate of all gynecological cancers and is the fifth leading cause of death among women [1]. About $90 \%$ of human ovarian cancers are thought to originate from the ovarian surface epithelium [2]. The rate of epithelial ovarian cancer is high because incessant ovulation causes genomic damage to the ovarian surface epithelium, increasing the possibility of gene mutations $[3,4]$. The lack of an appropriate animal model has prevented mechanistic studies of ovarian cancer [2].

Chickens ovulate almost every day, whereas women ovulate only once a month. Given the prevalent hypothesis that the cause of ovarian cancer is incessant ovulation [5], chickens that spontaneously develop epithelial ovarian cancer may be a good animal model for researching the mechanisms responsible for human

\footnotetext{
* Correspondence: ghsong@snu.ac.kr

† Contributed equally

WCU Biomodulation Major, Department of Agricultural Biotechnology, Seoul National University, 599 Gwanak-ro, Gwanak-gu, Seoul 151-921, Korea
}

ovarian cancer [6,7]. Furthermore, CA125, a well-known marker for human ovarian cancer, is expressed in chicken ovarian cancer cells, but not in normal ovarian cells $[6,8,9]$.

There are 11 cysteine cathepsins in human (CTSB, -C, $-\mathrm{F},-\mathrm{H},-\mathrm{K},-\mathrm{L},-\mathrm{O},-\mathrm{S},-\mathrm{V},-\mathrm{W}$, and $-\mathrm{X} / \mathrm{Z})$, which all share a conserved active site formed by cysteine and histidine residues [10]. The CTSs have functions in not only regulation of intracellular protein metabolism [11] but also bone resorption [12] and antigen presentation [13]. In addition, CTSs are involved in the degradation and remodeling of extracellular matrix and are associated with cell transformation, differentiation, motility, and adhesion [14]. These functions are also related to cancer cell invasion and metastasis $[15,16]$. CTSB is a marker for ovarian cancer prognosis [17] and may contribute to the invasion of ovarian cancer cells [18]. Nevertheless, no studies have investigated the expression of CTSs in chickens with ovarian cancer.

The purpose of this study is to confirm that the expression pattern of CTSs in human is replicated to 
some extent in the chicken. Therefore, the expression of all known CTSs was examined in normal and cancerous ovaries from chickens, and in situ hybridization was used to determine the cell-specific localization of CTSs differentially expressed between normal and cancerous ovaries.

\section{Methods}

\section{Animals}

The care and experimental use of White Leghorn (WL) chickens was approved by the Institute of Laboratory Animal Resources, Seoul National University (SNU070823-5). The WL chickens were maintained in a standard management program at the University Animal Farm, Seoul National University, Korea. The procedures for animal management, reproduction, and embryo manipulation followed standard operating protocols used in our laboratory.

\section{Tissue samples}

Cancerous $(\mathrm{n}=5)$ and normal $(\mathrm{n}=3)$ ovaries were collected from 2-to 3-year-old WL hens, and ovarian tissue samples were collected for study. We have examined the tumor stage in five chickens with cancerous ovaries according to characteristic features of chicken ovarian cancer previously reported [19]. In three hens, ovarian tumor seeding had metastasized to gastrointestinal tract and superficial surface in liver, and profuse ascites were detected in abdominal cavity. In the other two hens, the tumors had metastasized to distant organs with profuse ascites such as liver parenchyma, lung, gastrointestinal tract and oviduct. Therefore, former three and later two tumors were classified to the stage III and stage IV of chicken ovarian cancer, respectively. Subsets of these samples were frozen or paraffin-embedded for further analyses. Paraffin-embedded tissues were sectioned at 5 $\mu \mathrm{m}$ and stained with hematoxylin and eosin (H\&E). Epithelial ovarian cancers in chicken were classified based on the cellular subtypes and patterns of cellular differentiation with reference to ovarian malignant tumor types in humans. In this study, three types including serous $(n=2)$, endometrioid $(n=2)$, and clear cell $(n=1)$ were observed in chicken ovarian tumors.

\section{RT-PCR analysis}

Total RNA was extracted from frozen tissues by Trizol reagent (Invitrogen, Carlsbad, CA), and cDNAs were synthesized using AccuPower ${ }^{\circ}$ RT PreMix (Bioneer, Daejeon, Korea). The cDNA was serially diluted 10-fold and quantitatively equalized for PCR amplification using specific primer sets (Table 1). The PCR amplification was performed as follows: 1) $95^{\circ} \mathrm{C}$ for $3 \mathrm{~min}$;) $95^{\circ} \mathrm{C}$ for $20 \mathrm{~s}, 60^{\circ} \mathrm{C}$ for $40 \mathrm{~s}$, and $72^{\circ} \mathrm{C}$ for $1 \mathrm{~min}$ for 30 cycles
Table 1 Primers used for RT-PCR

\begin{tabular}{|c|c|c|c|}
\hline \multirow[t]{2}{*}{ Gene } & Sequence $\left(5^{\prime} \rightarrow 3^{\prime}\right)$ : & GenBank & \multirow[t]{2}{*}{$\begin{array}{l}\text { Product } \\
\text { Size (bp) }\end{array}$} \\
\hline & Forward and Reverse & Accession No. & \\
\hline CTSB & $\begin{array}{l}\text { AGGGCACAACTTCCACAACA } \\
\text { GCGAGTAGCCAGGTTCACAG }\end{array}$ & NM_205371.1 & 524 \\
\hline CTSC & $\begin{array}{l}\text { AAAGCCTGCCCCTCTAACAC } \\
\text { AGCCTACCAGCAAGACAGCA }\end{array}$ & XM_417207.2 & 590 \\
\hline CTSH & $\begin{array}{l}\text { GGGGCTIITTAGTGGCTCTG } \\
\text { GAAGTCGCTCGTCACCTCAA }\end{array}$ & XM_001232764.1\#1 & 560 \\
\hline CTSK & $\begin{array}{l}\text { GAGGAGGTGGTGAGGACGAT } \\
\text { AGAACTGGAAGGAGGGCAGA }\end{array}$ & NM_204971.1 & 526 \\
\hline CTSL & $\begin{array}{l}\text { CCTGATTTGGACAGCCACTG } \\
\text { AGCCTTGATTTCCTTCTGGG }\end{array}$ & NM_001168009.1 & 475 \\
\hline CTSO & $\begin{array}{l}\text { AGTGCCAAAGGGAGAGGAAA } \\
\text { CAAAGGACCCCAGTCAACAA }\end{array}$ & NM_001031129.1 & 427 \\
\hline CTSS & $\begin{array}{l}\text { GCACCCTCAACGAGAAGGA } \\
\text { GCACAGAGAAAATCACCCCC }\end{array}$ & NM_001031345.1 & 433 \\
\hline CTSZ & $\begin{array}{l}\text { GTCAACTACGCCAGCACCAC } \\
\text { CATIITCTACACCCCAGCCA }\end{array}$ & XM_417483.2 & 538 \\
\hline GAPDH & $\begin{array}{l}\text { CACAGCCACACAGAAGACGG } \\
\text { CCATCAAGTCCACAACACGG }\end{array}$ & NM_204305 & 443 \\
\hline
\end{tabular}

(CTSS and GAPDH), 35 cycles (CTSB, CTSC, CTSH, CTSK, CTSL, and CTSZ), or 40 cycles (CTSO); and 3) $72^{\circ} \mathrm{C}$ for $5 \mathrm{~min}$. The PCR products were analyzed using $1 \%$ agarose gels with ethidium bromide.

\section{Quantitative RT-PCR analysis}

Quantitative RT-PCR was performed using SYBR Green (Sigma, St. Louis, MO) and a StepOnePlus Real-Time PCR System (Applied Biosystems, Foster City, CA). Relative quantification of gene expression was calculated using the formula $2^{-\Delta \Delta \mathrm{Ct}}$, where $\Delta \Delta \mathrm{Ct}=\left(\mathrm{Ct}_{\text {target gene }}-\mathrm{Ct}_{G A P D H}\right)$ cancerous tissue $-\left(\mathrm{Ct}_{\text {target gene }}-\mathrm{Ct}_{\text {GAPDH }}\right)_{\text {normal tissue. The }}$ information for the primer sets is provided in Table 2.

\section{In situ hybridization analysis}

The expression of selected genes was examined using in situ hybridization as previously described [20]. For hybridization probes, PCR products were generated from ovarian cancer cDNA with the primers used for

Table 2 Primers used for quantitative RT-PCR

\begin{tabular}{|c|c|c|c|}
\hline \multirow[t]{2}{*}{ Gene } & Sequence $\left(5^{\prime} \rightarrow 3^{\prime}\right)$ : & GenBank & $\begin{array}{l}\text { Product Size } \\
\text { (bp) }\end{array}$ \\
\hline & Forward and Reverse & Accession No. & \\
\hline CTSB & $\begin{array}{l}\text { GCACTACGGCATCACATCCT } \\
\text { AACCTGCTCCCCTGACACAT }\end{array}$ & NM_205371.1 & 157 \\
\hline CTSC & $\begin{array}{l}\text { CTGGAGAAATGTGAATGGCG } \\
\text { CTGGGGACTGAAGACTGGCT }\end{array}$ & XM_417207.2 & 151 \\
\hline CTSS & $\begin{array}{l}\text { TGCCACGTGCTCCAAGTATG } \\
\text { CGTGGTTCACCTCCTGTGTG }\end{array}$ & NM_001031345.1 & 173 \\
\hline GAPDH & $\begin{array}{l}\text { ACACAGAAGACGGTGGATGG } \\
\text { GGCAGGTCAGGTCAACAACA }\end{array}$ & NM_204305 & 193 \\
\hline
\end{tabular}


RT-PCR analysis. The products were gel-extracted and cloned into pGEM-T Easy Vector (Promega). All plasmids were sequenced using T7 and SP6 primers to certain the genes as expected. After verification of the sequences, a DIG-labeled RNA probe was prepared using a DIG RNA labeling kit (Roche Applied Science, Indianapolis, IN). Frozen sections $(10 \mu \mathrm{m})$ were mounted on slides pretreated with 3-aminopropyltriethoxysilane (APES, Sigma), dried on a $50^{\circ} \mathrm{C}$ slide warmer, and fixed in $4 \%$ paraformaldehyde in phosphate-buffered saline (PBS). The sections were treated with $1 \%$ Triton X-100 in PBS for 20 min and washed three times in PBS. The sections were incubated in a prehybridization mixture containing $50 \%$ formamide and $5 \times$ standard saline citrate (SSC) for $15 \mathrm{~min}$ at room temperature. After prehybridization, the sections were incubated with a hybridization mixture containing 50\% formamide, $5 \times \mathrm{SSC}, 10 \%$ dextran sulfate sodium salt, $0.02 \%$ bovine serum albumin, $250 \mu \mathrm{g} / \mathrm{ml}$ yeast tRNA, and denatured DIG-labeled cRNA probe for $18 \mathrm{~h}$ at $55^{\circ}$ $\mathrm{C}$ in a humidified chamber. The sections were washed for stringency in a series of solutions containing formamide and SSC. After blocking with a $1 \%$ blocking reagent (Roche), the sections were incubated overnight with sheep anti-DIG antibody conjugated to alkaline phosphatase (Roche). The signal was visualized by exposure to a solution containing $0.4 \mathrm{mM} 5$-bromo-4chloro-3-indolyl phosphate, $0.4 \mathrm{mM}$ nitroblue tetrazolium, and $2 \mathrm{mM}$ levamisole (Sigma). All sections were counterstained with $1 \%(\mathrm{w} / \mathrm{v})$ methyl green (Sigma), and photographs were taken using a Zeiss Axiophot light microscope equipped with an Axiocam HRc camera (Carl Zeiss).

\section{Immunohistochemistry}

The candidate hens with either normal or cancerous ovaries were sacrificed, and their ovaries were collected and fixed in $4 \%$ paraformaldehyde. The tissues were embedded in paraffin and sectioned at $5 \mu \mathrm{m}$ on APEStreated (silanized) slides. The sections were then deparaffinized in xylene and rehydrated to water through a graded series of alcohol. After antigen retrieval by boiling in a citrate buffer $(10 \mathrm{mM})$, the sections were incubated with either mouse anti-PCNA IgG (monoclonal antibody raised against recombinant rat PCNA, Santa Cruz Biotechnology, Santa Cruz, CA), mouse anti-vimentin IgG (monoclonal antibody raised against vimentin purified form bovine lens, Millipore, Billerica, MA), mouse anti-ERBB2 IgG (monoclonal antibody raised against a synthetic peptide from the Cterminus of human ERBB2 protein, Thermo Fisher Scientific, Waltham, MA), or rabbit anti-CTSB IgG (polyclonal antibody raised against recombinant rat procathepsin B, Millipore). Mouse and rabbit IgG were used as negative controls. All antibodies were used at $2 \mu \mathrm{g} / \mathrm{ml}$ in PBS containing 1\% BSA. The slides were then treated with an avidin-biotin-peroxidase complex according to the manufacturer's instructions (Vector Laboratories, Burlingame, CA) and visualized using diaminobenzidine tetrahydrochloride (Sigma) as a color substrate. After visualization, the sections were coverslipped using Permount (Fisher Scientific, Pittsburgh, PA).

\section{Statistical analyses}

All statistical analyses were performed using Student's t test using the SAS program (SAS Institute, Cary, NC, USA). Differences were considered significant at a value of $P<0.05$.

\section{Results}

\section{Pathological characteristics of chicken ovarian cancer}

Cancerous ovaries from chickens differed morphologically from normal ovaries. The normal chicken ovary contained large yellow follicles that were hierarchically arranged by stage (Fig. 1A). However, the cancerous ovary was more solid and possessed surface tumor lesions and atretic follicles, indicating abnormal ovarian function (Fig. 1B). Further histological analysis after $\mathrm{H} \& \mathrm{E}$ staining of normal and cancerous ovaries revealed that normal ovaries contained follicles surrounded by connective tissue (Fig. 1C), whereas cancerous ovaries consisted primarily of nodule structures in the solid portion of the ovary (Fig. 1D). These morphological differences between normal and cancerous ovaries were very similar to those reported previously [21-24].

\section{Immunohistochemical characterization of chicken ovarian cancer}

We performed immunohistochemistry to further characterize cancerous chicken ovaries based on reports that proliferating cell nuclear antigen (PCNA), vimentin, and ERBB2 proteins were detected in cancerous ovaries of chickens $[8,25,26]$. In the present study, immunoreactive PCNA was detected in granulosa cells surrounding follicles in normal ovaries (Fig. 2A and 2B), and vimentin was localized to the cells surrounding the granulosa cell layer and blood vessels (Fig. 2C and 2D). ERBB2 was also weakly expressed in glands and blood vessels (Fig. $2 \mathrm{E}$ and $2 \mathrm{~F}$ ). In cancerous ovaries, PCNA protein was predominantly detected in the nucleus of cancerous cells in the nodule area (Fig. 2G and $2 \mathrm{H}$ ). However, vimentin was not expressed in cancerous areas of the ovaries, but was detected in blood vessels (Fig. 2I and 2J). ERBB2 was localized to the cytoplasm in the nodule area of cancerous ovaries (Fig. $2 \mathrm{~K}$ and $2 \mathrm{~L}$ ). 

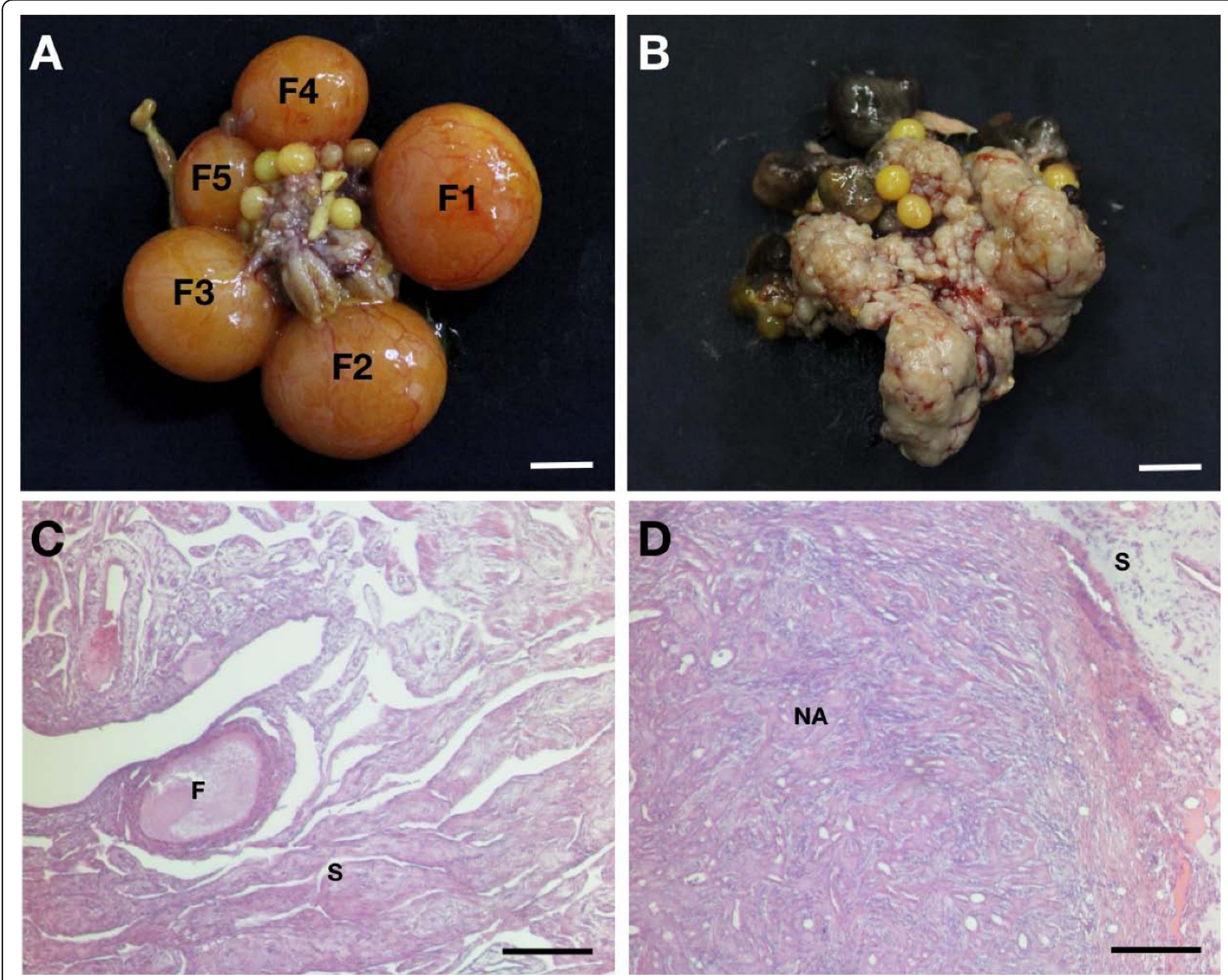

Figure 1 Pathological characteristics of normal and cancerous chicken ovaries. Follicles are hierarchically arranged by stage of development (F1-F5) in the normal ovary (A). The cancerous ovary has surface tumor lesions and atretic follicles (B). Hematoxylin and eosin staining of normal (C) and cancerous (D) ovaries from hens. F, follicle; S, stroma; NA, nodule area. Scale bar $=1 \mathrm{~cm}$ (A and B) or $100 \mu \mathrm{m}$ (C and D).

Differential expression of CTSB, CTSC, and CTSS in normal and cancerous ovaries

Based on the morphological and immunohistochemical differences between normal and cancerous hen ovaries, we hypothesized that expression patterns of the various CTSs related to cancer may differ between normal and cancerous tissues. First, the expression of all known CTSs in cancerous chicken ovaries was examined by RT-PCR analysis, and six CTSs were found to be expressed in both normal and cancerous ovaries (Fig. 3). CTSH and CTSK were not detected by RT-PCR (data not shown).

In situ hybridization analysis was used to determine cell-specific localization of CTSB, CTSC, and CTSS mRNAs (Fig. 4). CTSB was expressed at a low level around follicles in the normal ovaries, but there was strong expression of CTSB mRNA in the nodule area in cancerous ovaries. Similarly, there was localization of CTSC mRNA around follicles in normal ovaries, whereas CTSC mRNA was weakly expressed in the nodule area of cancerous ovaries. Although there was also localization of CTSS mRNA around follicles in normal ovaries, CTSS mRNA was abundant in the nodule area of cancerous ovaries. Further analysis using quantitative RT-PCR indicated that mRNA expression levels for CTSB, CTSC, and CTSS were higher in cancerous ovaries $(P<0.05$, Fig. 5$)$.

\section{Localization of immunoreactive CTSB protein in cancerous ovaries}

We further confirmed the localization of immunoreactive CTSB protein by immunohistochemistry and found 


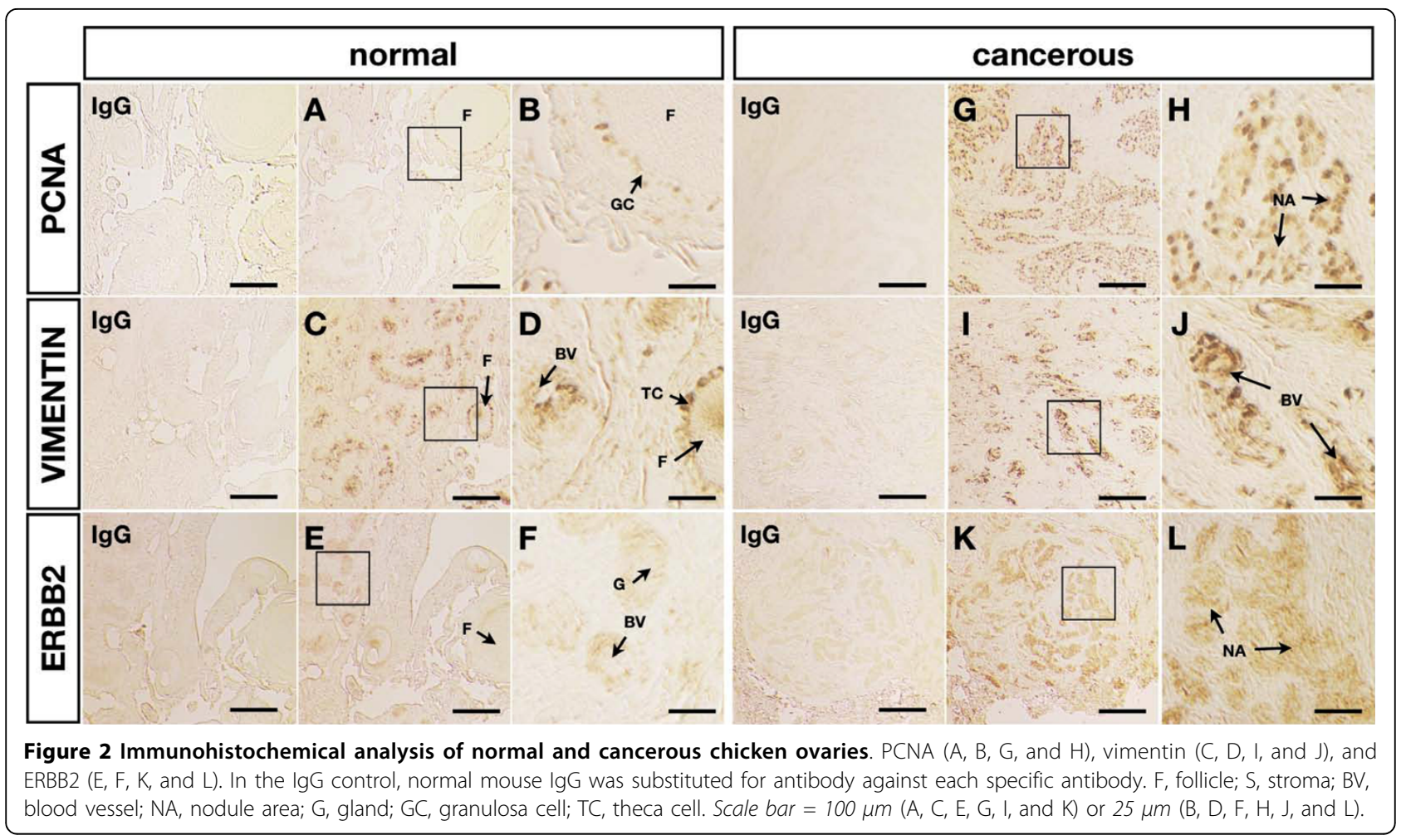

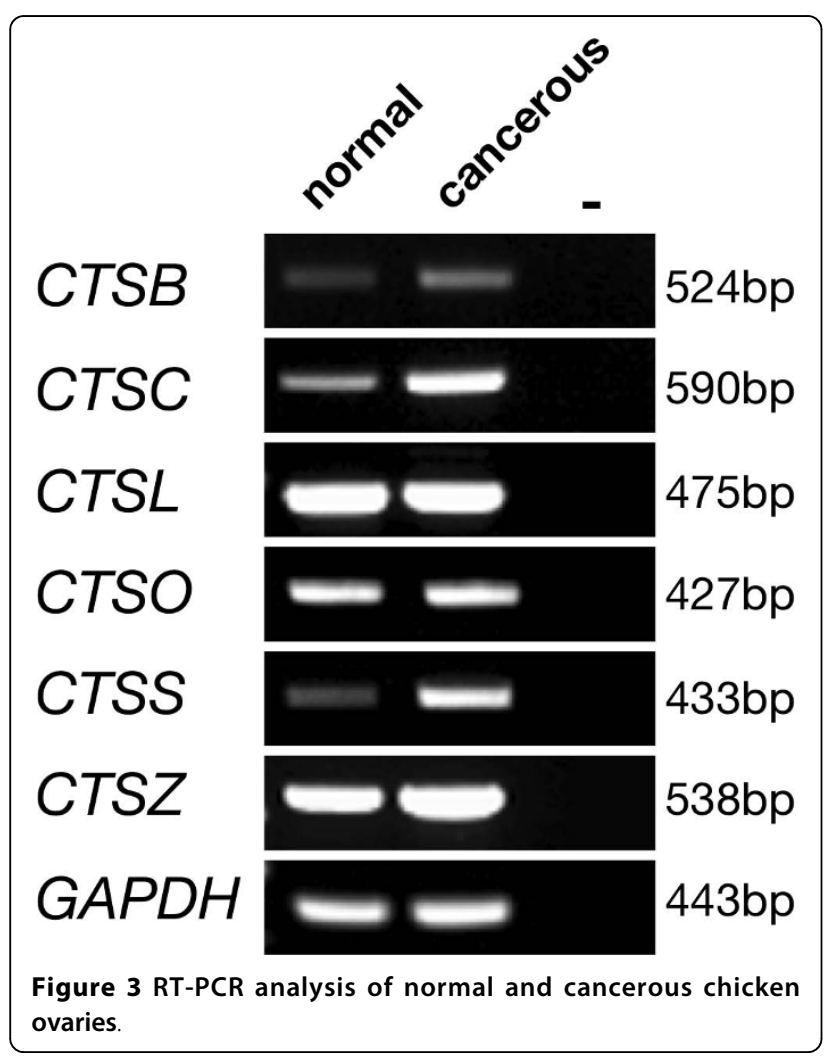

regions of staining around follicles in normal ovaries (Fig. 6A); however, CTSB protein was detected in the nodule area in cancerous ovaries (Fig. 6B and 6C) which was consistent with the differential expression of normal and cancerous ovarian CTSB mRNA (Fig. 4 and 5). Moreover, CTSB was identified in the cytoplasm of tumor cells (Fig. 6B) showing different pattern from staining with anti-PCNA antibody in which PCNA was identified in nucleus (Fig. 2G and $2 \mathrm{H}$ ).

\section{Discussion}

The mechanisms responsible for the development of ovarian cancer are not fully understood owing to the lack of a suitable ovarian cancer animal model [2]. However, the laying hen has received attention as a model for ovarian cancer research because of significant similarities between ovarian cancers of hens and women. Ovarian adenocarcinomas originate predominantly from the ovarian epithelium and are associated with incessant ovulation in both species $[3,5,27]$. The laying hen model strongly supports the incessant ovulation theory, as hens ovulate almost every day and exhibit high rates of spontaneous development of ovarian adenocarcinoma [6,27]. Also, several anti-tumor antibody antigens (e.g., cytokeratin, PCNA, COX-1, COX-2, CEA, AE1/AE3, EGER, ERBB2, Lewis Y, SELENBP1, p53 and Tag 72) that are commonly used as markers for human ovarian cancer 


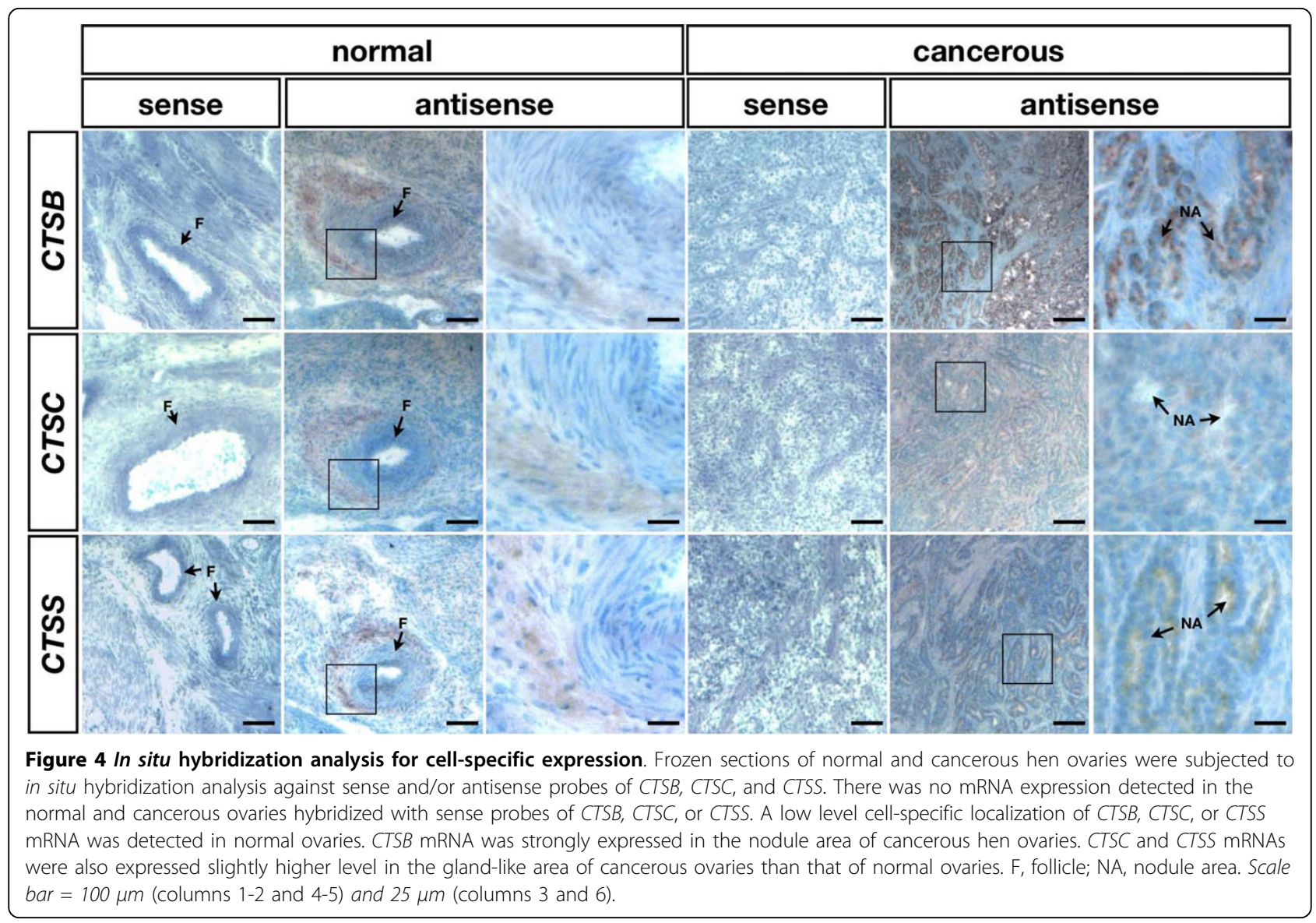

are also detected in ovarian carcinomas of hens $[6,8,21,23,24,26,28,29]$.

Proteases, which catalyze the cleavage of peptide bonds in proteins, can be divided into five categories: metalloproteases, cysteine proteases, serine proteases, aspartic proteases, and threonine proteases [30]. CTSs are a family of cysteine proteases that function primarily in protein degradation in the lysosomes of the majority of cell types [11]. However, specific CTSs are often upregulated in various cancers [31]. CTSs are expressed at the cell surface of cancer cells and secreted into the extracellular space, where they degrade ECM

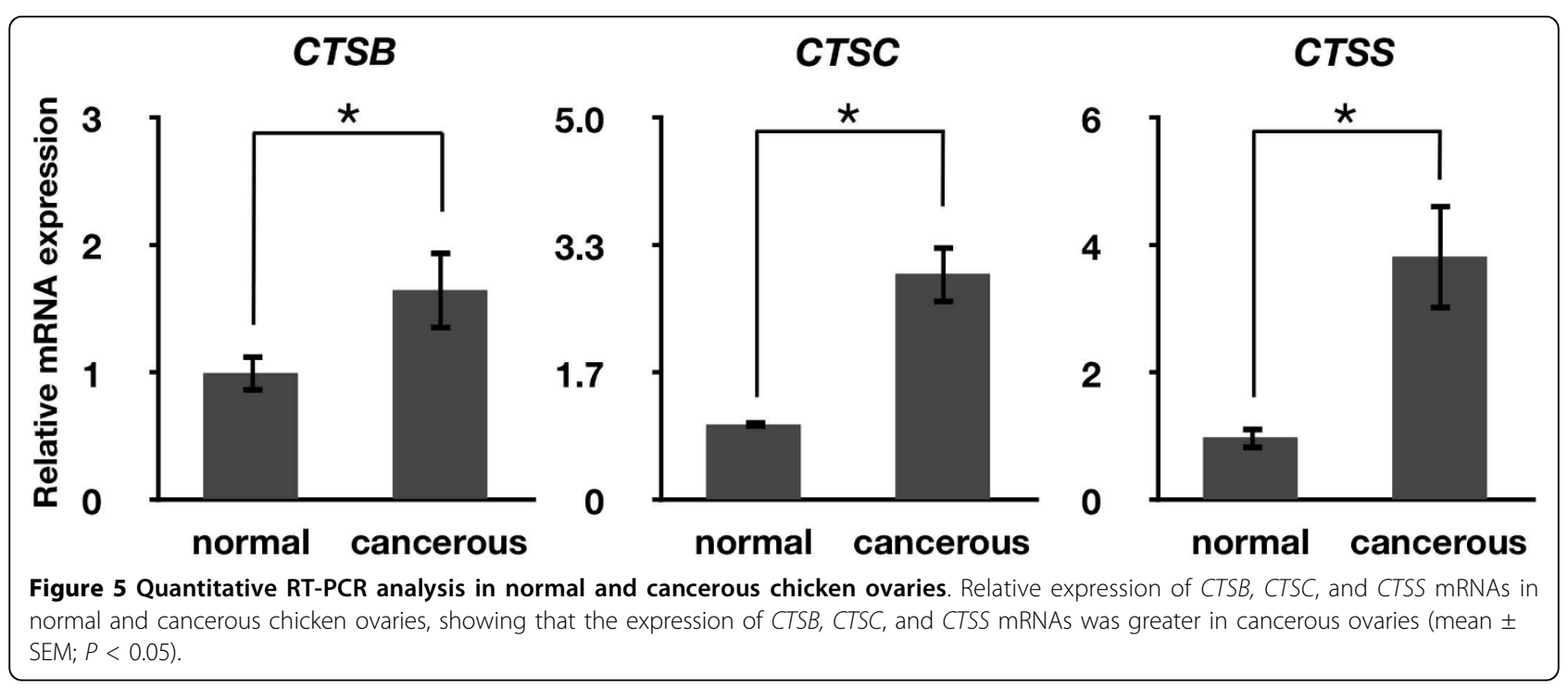




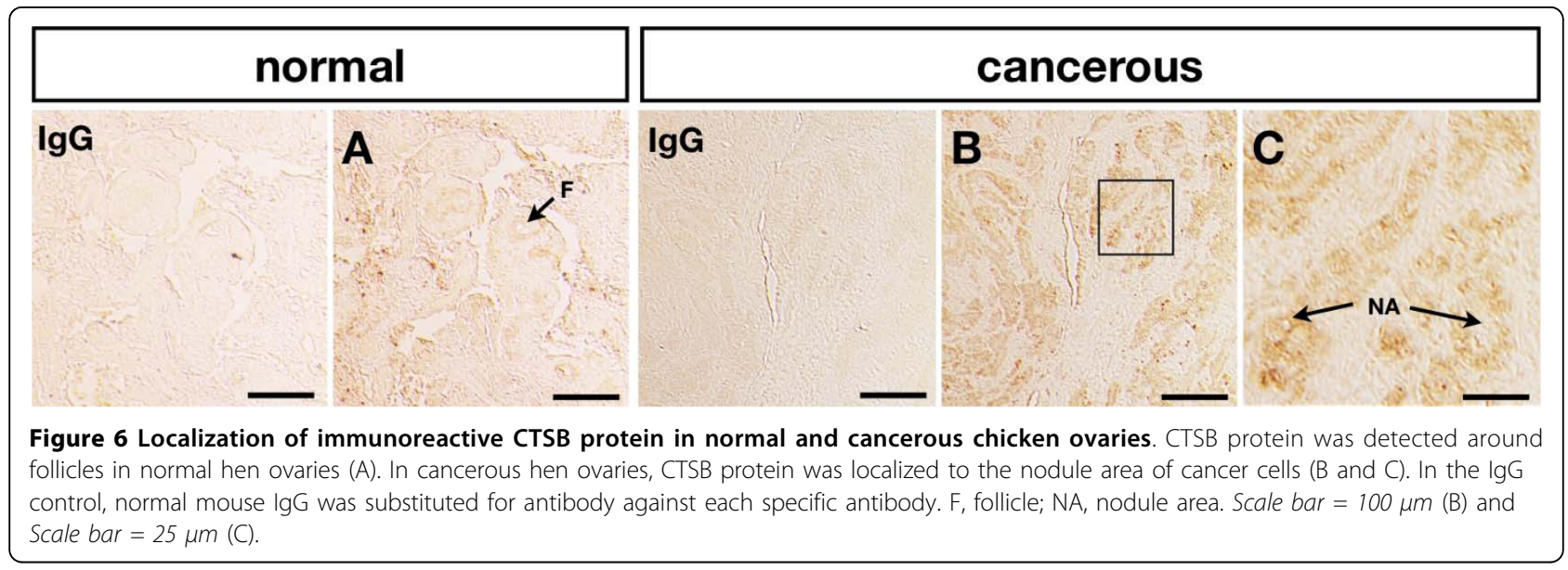

components [15,32]. This extracellular proteolytic activity allows cancer cells to invade surrounding tissue, blood, and lymph vessels and to metastasize to tissues at distant sites [33]. These important roles of CTSs in cancer development encouraged us to examine the expression of CTSs in the chicken ovarian cancer model. Specific expression of CTSB, CTSC, and CTSS was clearly observed in cancerous ovaries of hens.

Among the CTSs, CTSB has been investigated most intensively and appears to play a role in cancer based on its increased expression in various human cancers [34-36]. A role of CTSB in tumor cell invasion was suggested by the increased invasiveness of cells overexpressing CTSB [37] and by decreased invasion in the presence of specific inhibitors of CTSB [38]. Women with ovarian cancer have higher levels of CTSB in their sera [39], and CTSB is present in ascites and cyst fluid of patients with ovarian cancer [40,41]. Moreover, immunohistochemical analysis has shown that CTSB is evident in the cytoplasm of tumor cells in human ovarian cancer $[18,42]$. Similarly, the results of the present study indicate increased expression of CTSB in cancerous, but not normal, chicken ovaries. This suggests that the role for CSTB in tumor invasion in chickens may be similar to that in human ovarian cancer.

In addition to CTSB, other CTSs have been proposed as participants in the angiogenesis and invasion of tumor cells. For example, Ctss-deficient mice displayed defective microvessel development during wound repair, owing to the reduced ability of endothelial cells to invade the ECM [43]. In a murine model of sporadic pancreatic carcinogenesis, null mutant $C t s b$ and $C t s s$ mice exhibit decreased tumor invasion and angiogenesis $[44,45]$. Another study demonstrated that both CTSB and CTSS are upregulated in the transition from normal to angiogenic islets and that CTSC is expressed concomitantly with the development of angiogenic islets in mouse pancreatic islet tumors [46]. In the present study, the expression of CTSS and CTSC was also detected in cancerous ovaries of hens, suggesting that CTSS and CTSC may also play roles in the angiogenesis and invasion of tumor cells.

\section{Conclusions}

The results of the present study demonstrate that CTSB, CTSC, and CTSS are upregulated in cancerous ovaries of chickens, suggesting that CTSB, CTSC, and CTSS have potentially important functions in the development of ovarian cancer in chickens. Our study, therefore, provides a basis for the development of the hen as an animal model for the study of human ovarian cancer and for the discovery of the mechanisms responsible for the development of ovarian cancer.

\section{Acknowledgements}

We thank Yong-Sang Song, MD, PhD and Jeong Mook Lim, DVM, PhD (WCU Biomodulation Major, Department of Agricultural Biotechnology, Seoul National University) for pathologic diagnosis of chicken ovarian cancer. This work was supported by grants from the Korea Science and Engineering Foundation (KOSEF) (R01-2007-000-20456-0) and the World Class University (WCU) program (R31-10056) through the National Research Foundation of Korea funded by the Ministry of Education, Science, and Technology. The authors are appreciative of Dr. Fuller W. Bazer (Texas A\&M University, USA and Seoul National University, Korea) for manuscript preparation and helpful discussions.

\section{Authors' contributions}

GS coordinated all steps of the study. SEA and JWC carried out all the experimental procedures and data. DR carried out the in situ hybridization analysis. HWS and LW examined and selected the images. JYH interpreted and analyzed the results. All authors participated in the design and writing of this study. All authors read and approved the final manuscript.

\section{Competing interests}

The authors declare that they have no competing interests.

Received: 27 May 2010 Accepted: 21 August 2010

Published: 21 August 2010

\section{References}

1. Jemal A, Thomas A, Murray T, Thun M: Cancer statistics, 2002. CA Cancer J Clin 2002, 52(1):23-47. 
2. Orsulic S: Ovarian Cancer. Mouse Models of Human Cancer New Jersey: Whiley-Liss, IncHolland EC 2004, 171-187.

3. Murdoch WJ, Van Kirk EA, Alexander BM: DNA damages in ovarian surface epithelial cells of ovulatory hens. Exp Biol Med (Maywood) 2005, 230(6):429-433.

4. Auersperg N, Edelson Ml, Mok SC, Johnson SW, Hamilton TC: The biology of ovarian cancer. Semin Oncol 1998, 25(3):281-304

5. Fathalla MF: Incessant ovulation-a factor in ovarian neoplasia? Lancet 1971, 2(7716):163.

6. Johnson KA: The Standard of Perfection: Thoughts about the Laying Hen Model of Ovarian Cancer. Cancer Prev Res (Phila Pa) 2009, 2(2):97-99.

7. Murdoch WJ, Van Kirk EA, Alexander BM: DNA damages in ovarian surface epithelial cells of ovulatory hens. Exp Biol Med 2005, 230(6):429-433.

8. Jackson E, Anderson K, Ashwell C, Petitte J, Mozdziak PE: CA125 expression in spontaneous ovarian adenocarcinomas from laying hens. Gynecol Oncol 2007, 104(1):192-198.

9. Anderson GL, Mclntosh M, Wu L, Barnett M, Goodman G, Thorpe JD, Bergan L, Thornquist MD, Scholler N, Kim N, O'Briant K, Drescher C, Urban N: Assessing lead time of selected ovarian cancer biomarkers: a nested case-control study. J Nat/ Cancer Inst 2010, 102(1):26-38.

10. Turk D, Guncar G: Lysosomal cysteine proteases (cathepsins): promising drug targets. Acta Crystallogr D Biol Crystallogr 2003, 59(Pt 2):203-213.

11. Turk V, Turk B, Turk D: Lysosomal cysteine proteases: facts and opportunities. EMBO J 2001, 20(17):4629-4633.

12. Saftig $\mathrm{P}$, Hunziker $\mathrm{E}$, Wehmeyer $\mathrm{O}$, Jones $\mathrm{S}$, Boyde A, Rommerskirch W, Moritz JD, Schu P, von Figura K: Impaired osteoclastic bone resorption leads to osteopetrosis in cathepsin-K-deficient mice. Proc Natl Acad Sci USA 1998, 95(23):13453-13458.

13. Shi GP, Villadangos JA, Dranoff G, Small C, Gu L, Haley K, Riese R, Ploegh HL, Chapman HA: Cathepsin S required for normal MHC class II peptide loading and germinal center development. Immunity 1999, 10(2):197-206

14. Obermajer N, Jevnikar Z, Doljak B, Kos J: Role of cysteine cathepsins in matrix degradation and cell signalling. Connect Tissue Res 2008, 49(3):193-196.

15. Gocheva V, Joyce JA: Cysteine cathepsins and the cutting edge of cancer invasion. Cell Cycle 2007, 6(1):60-64.

16. Gupta GP, Massague J: Cancer metastasis: building a framework. Cell 2006, 127(4):679-695.

17. Scorilas A, Fotiou S, Tsiambas E, Yotis J, Kotsiandri F, Sameni M, Sloane BF, Talieri M: Determination of cathepsin B expression may offer additional prognostic information for ovarian cancer patients. Biol Chem 2002, 383(7-8):1297-1303.

18. Nishikawa H, Ozaki Y, Nakanishi T, Blomgren K, Tada T, Arakawa A, Suzumori K: The role of cathepsin B and cystatin C in the mechanisms of invasion by ovarian cancer. Gynecol Oncol 2004, 92(3):881-886.

19. Barua A, Bitterman P, Abramowicz JS, Dirks AL, Bahr JM, Hales DB, Bradaric MJ, Edassery SL, Rotmensch J, Luborsky JL: Histopathology of ovarian tumors in laying hens: a preclinical model of human ovarian cancer. Int J Gynecol Cancer 2009, 19(4):531-539.

20. Rengaraj D, Kim DK, Zheng YH, Lee SI, Kim H, Han JY: Testis-specific novel transcripts in chicken: in situ localization and expression pattern profiling during sexual development. Biol Reprod 2008, 79(3):413-420.

21. Zhuge Y, Lagman JA, Ansenberger K, Mahon CJ, Daikoku T, Dey SK, Bahr JM, Hales DB: CYP1B1 expression in ovarian cancer in the laying hen Gallusdomesticus. Gynecol Oncol 2009, 112(1):171-178.

22. Ansenberger $K$, Zhuge $Y$, Lagman JA, Richards C, Barua A, Bahr JM, Hales DB: E-cadherin expression in ovarian cancer in the laying hen, Gallus domesticus, compared to human ovarian cancer. Gynecol Oncol 2009, 113(3):362-369

23. Hales DB, Zhuge Y, Lagman JA, Ansenberger K, Mahon C, Barua A, Luborsky JL, Bahr JM: Cyclooxygenases expression and distribution in the normal ovary and their role in ovarian cancer in the domestic hen (Gallus domesticus). Endocrine 2008, 33(3):235-244.

24. Urick ME, Johnson PA: Cyclooxygenase 1 and 2 mRNA and protein expression in the Gallus domesticus model of ovarian cancer. Gynecol Oncol 2006, 103(2):673-678.

25. Giles JR, Shivaprasad HL, Johnson PA: Ovarian tumor expression of an oviductal protein in the hen: a model for human serous ovarian adenocarcinoma. Gynecol Oncol 2004, 95(3):530-533.
26. Rodriguez-Burford C, Barnes MN, Berry W, Partridge EE, Grizzle WE: Immunohistochemical expression of molecular markers in an avian model: a potential model for preclinical evaluation of agents for ovarian cancer chemoprevention. Gynecol Oncol 2001, 81(3):373-379.

27. Giles JR, Olson LM, Johnson PA: Characterization of ovarian surface epithelial cells from the hen: a unique model for ovarian cancer. Exp Biol Med (Maywood) 2006, 231(11):1718-1725.

28. Stammer K, Edassery SL, Barua A, Bitterman P, Bahr JM, Hales DB, Luborsky JL: Selenium-Binding Protein 1 expression in ovaries and ovarian tumors in the laying hen, a spontaneous model of human ovarian cancer. Gynecol Oncol 2008, 109(1):115-121.

29. Hakim AA, Barry CP, Barnes HJ, Anderson KE, Petitte J, Whitaker R, Lancaster JM, Wenham RM, Carver DK, Turbov J, Berchuck A, Kopelovich L, Rodriguez GC: Ovarian adenocarcinomas in the laying hen and women share similar alterations in p53, ras, and HER-2/neu. Cancer Prev Res (Phila Pa) 2009, 2(2):114-121.

30. Rawlings ND, Barrett AJ, Bateman A: MEROPS: the peptidase database. Nucleic Acids Res 2010, 38(Database issue):D227-233.

31. Jedeszko C, Sloane BF: Cysteine cathepsins in human cancer. Biol Chem 2004, 385(11):1017-1027.

32. Mohamed MM, Sloane BF: Cysteine cathepsins: multifunctional enzymes in cancer. Nat Rev Cancer 2006, 6(10):764-775.

33. Lankelma JM, Voorend DM, Barwari T, Koetsveld J, Van der Spek AH, De Porto AP, Van Rooijen G, Van Noorden CJ: Cathepsin L, target in cancer treatment? Life Sci 2010, 86(7-8):225-233.

34. Yan S, Sameni M, Sloane BF: Cathepsin B and human tumor progression. Biol Chem 1998, 379(2):113-123.

35. Lah TT, Kos J: Cysteine proteinases in cancer progression and their clinical relevance for prognosis. Biol Chem 1998, 379(2):125-130.

36. Rao JS: Molecular mechanisms of glioma invasiveness: the role of proteases. Nat Rev Cancer 2003, 3(7):489-501.

37. Szpaderska AM, Frankfater $A$ : An intracellular form of cathepsin $B$ contributes to invasiveness in cancer. Cancer Res 2001, 61(8):3493-3500.

38. Premzl A, Zavasnik-Bergant V, Turk V, Kos J: Intracellular and extracellular cathepsin B facilitate invasion of MCF-10A neoT cells through reconstituted extracellular matrix in vitro. Exp Cell Res 2003, 283(2):206-214.

39. Warwas M, Haczynska H, Gerber J, Nowak M: Cathepsin B-like activity as a serum tumour marker in ovarian carcinoma. Eur I Clin Chem Clin Biochem 1997, 35(4):301-304.

40. Kolwijck E, Massuger LF, Thomas CM, Span PN, Krasovec M, Kos J, Sweep FC: Cathepsins B, L and cystatin C in cyst fluid of ovarian tumors. J Cancer Res Clin Oncol 2009.

41. Lah TT, Kokalj-Kunovar M, Kastelic L, Babnik J, Stolfa A, Rainer S, Turk V: Cystatins and stefins in ascites fluid from ovarian carcinoma. Cancer Lett 1992, 61(3):243-253.

42. Scorilas A, Fotiou S, Tsiambas E, Yotis J, Kotsiandri F, Sameni M, Sloane BF, Talieri M: Determination of cathepsin B expression may offer additional prognostic information for ovarian cancer patients. Biol Chem 2002, 383(7-8):1297-1303.

43. Shi GP, Sukhova GK, Kuzuya M, Ye Q, Du J, Zhang Y, Pan JH, Lu ML, Cheng XW, Iguchi A, Perrey S, Lee AM, Chapman HA, Libby P: Deficiency of the cysteine protease cathepsin $S$ impairs microvessel growth. Circ Res 2003, 92(5):493-500.

44. Burden RE, Gormley JA, Jaquin TJ, Small DM, Quinn DJ, Hegarty SM, Ward C, Walker B, Johnston JA, Olwill SA, Scott CJ: Antibody-mediated inhibition of cathepsin $S$ blocks colorectal tumor invasion and angiogenesis. Clin Cancer Res 2009, 15(19):6042-6051.

45. Gocheva V, Zeng W, Ke D, Klimstra D, Reinheckel T, Peters C, Hanahan D, Joyce JA: Distinct roles for cysteine cathepsin genes in multistage tumorigenesis. Genes Dev 2006, 20(5):543-556.

46. Joyce JA, Baruch A, Chehade K, Meyer-Morse N, Giraudo E, Tsai FY, Greenbaum DC, Hager JH, Bogyo M, Hanahan D: Cathepsin cysteine proteases are effectors of invasive growth and angiogenesis during multistage tumorigenesis. Cancer Cell 2004, 5(5):443-453.

doi:10.1186/1477-7827-8-100

Cite this article as: Ahn et al:: Increased expression of cysteine cathepsins in ovarian tissue from chickens with ovarian cancer. Reproductive Biology and Endocrinology 2010 8:100. 